УДК 37.01:82-1

DOI https://doi.org/10.32782/apv/2021.6.2

\title{
Ірина СНГАЛИЧЕВА
}

кандидат педагогічних наук, доцент кафедри дошкільної освіти, Черкаський національний університет імені Богдана Хмельницького, бул. Шевченка, 81, м. Черкаси, Україна, 18000

ORCID: 0000-0001-6824-9548

Бібліографічний опис статті: Снгаличева, І. (2021). Можливості використання ігрової діяльності під час ознайомлення дітей дошкільного віку з літературними творами. Acta Paedagogica Volynienses, 6, 9-14, doi: https://doi.org/10.32782/apv/2021.6.2

\section{МОЖЛИВОСТІ ВИКОРИСТАННЯ ІГРОВОї ДІЯЛЬНОСТІ ПІД ЧАС ОЗНАЙОМЛЕННЯ ДІТЕЙ ДОШКІЛЬНОГО ВІКУ 3 ЛІТЕРАТУРНИМИ ТВОРАМИ}

Збереження та змічнення здоров'я дитини, ї самоичінності є периочерговим завданням сім'ї та закладів дошкільної освіти. На иъьому наголошується у Державному освітньому стандарті дошкільної освіти, щцо визначає очікування суспільства з питань розвиненості, вихованості та освіченості дитини дошкільного віку, передбачає наявність сформованих у дитини компетентностей, які вказують на можливість активно проявляти особистісні надбання в різних самостійних та організованих за підтримки дорослого видах діяльності. Серед ключових для дошкільної освіти компетентностей нашу увагу привертає ігрова та художньо-мовленнєва. Саме ігрова компетентність реалізує можливість дитини застосовувати наявні та освоювати нові знання через провідний вид діяльності, а художньо-мовленнєва - відтворювати художньо-естетичні враження від сприйняття літературних і фольклорних творів засобами різних видів художньо-мовленнєвої діяльності.

Значний внесок у розвиток ігрової діяльності зробили Г. Костюк, С. Русова, В. Сухомлинський, К. Ушинський та інші. На роль ігрової діяльності в розвитку і вихованні дошкільників вказували О. Безсонова, А. Богуш, Н. Бібік, А. Бондаренко, Н. Гавриш, А. Матусик, Д. Менджерицька, Т. Піроженко, І. Сікорський, О. Савченко, М. Шуть та інші. Художня література як вид діяльності, що сприяє розвитку дошкільників, була предметом дослідження А. Богуш, Н. Гавриш, В. Кузьменко, Д. Луценко, О. Кононко та інших. Проте, незважаючи на значну кількість досліджень у ичьому напрямі, недостатньо дослідженим є питання організації ігрової діяльності у процесі ознайомлення дошкільників із художньою літературою.

3 огляду на це, мета статті - дослідити стан використання різних видів ігрової діяльності під час ознайомлення дітей дошкільного віку із творами художньої літератури та запропонувати можливі способи використання ігрових форм роботи під час ознайомлення дітей дошкільного віку із художніми творами.

Відомо, щяо ігрова діяльність є найдоступнішим видом діяльності для дітей дошкільного віку, оскільки відповідає психічним властивостям дошкільників та сприяє розвитку їхніх інтересів та здібностей. Існує безліч класифікачій щодо видів ігрової діяльності: режисерські, сюжетно-рольові, конструкторсько-будівельні, ігри на теми літературних творів, рухливі, дидактичні, народні ігри тощуо. Зрозуміло, шуо творчий вихователь у своїй діяльності зможе використати будь-який вид гри під час ознайомлення дітей із літературними творами (як із малим жанровим фольклором, так $і$ з авторськими творами).

Зазначимо, щео, ознайомлюючи дітей із фольклором (забавлянками, примовками, мирилками, закличками тощо), можна запропонувати рухливі ігри, а для їх розучування можна використовувати мнемотаблиці. Під час читання та засвоєння казок (народних чи літературних) доречним буде проведення сюжетно-рольових або театралізованих ігор. Окрім того, існує багато дидактичних ігор, які сприятимуть кращуому розумінню та аналізу дітьми змісту прочитаних казок. Серед таких дидактичних ігор можна назвати «Які права порушено у героїв казок», «Знайди в казиі (творі) пару», «Відшукай тінь», «Впізнай казку за малюнком», «Збери казку», «Лото» тощу. Під час вивчення віршів (наприклад, П. Воронько «Їжачок-хитрячок», «Падав сніг на поріг», М. Познанська «Ромашка», П. Тичина «А я у гай ходила» тощо) та переказу творів (наприклад, Л. Українки «Мамо, іде вже зима», «Вишеньки», «На зеленому горбочку» тощя) можна використати мнемотаблиці або круги Лулія, які також використовують як дидактичну гру.

Використання будь-яких ігор під час ознайомлення дітей із художніми творами сприяє розвитку у них пам'яті, уваги, закріпленню набутих знань і формуванню уміння використовувати їх на практиці. Головне, щзо процес навчання відбувається у иікавій формі та сприяє задоволенню однієї із природних потреб дошкільників - потреби у грі.

Отже, розвиток креативності дошкільників буде залежати від творчого підходу дорослих у навчанні та вихованні дітей. Пропоновані нами види ігор під час ознайомлення дітей дошкільного віку з літературними творами не обмежують широкі можливості для інтеграції різних видів діяльності у роботі з дітьми дошкільного віку. Перспективи подальшого дослідження вбачаємо у дослідженні використання IT-технологій під час ознайомлення дітей дошкільного віку з літературними творами. 
Ключові слова: гра, ігрова діяльність, сюжетно-рольова гра, театралізовані гра, дидактична гра, художня література, фольклор.

\section{Irina YENGALYCHEVA}

Candidate of Pedagogical Sciences, Associate Professor at the Department of Preschool Education, Cherkasy National University named after Bohdan Khmelnytsky, Shevchenko bul., 81, Cherkasy, Ukraine, 18000

ORCID: 0000-0001-6824-9548

To cite this article: Yengalycheva, I. (2021). Mozhlyvosti vykorystannja ighrovoji dijaljnosti pid chas oznajomlennja ditej doshkiljnogho viku $\mathrm{z}$ literaturnymy tvoramy [Opportunities to use gaming activities during acquaintance of preschool children with literary works]. Acta Paedagogica Volynienses, 6, 9-14, doi: https://doi.org/10.32782/apv/2021.6.2

\section{OPPORTUNITIES TO USE GAME ACTIVITIES DURING INTRODUCTION TO PRESCHOOL CHILDREN WITH LITERARY WORKS}

Preserving and strengthening the child's health and self-worth is a priority for families and preschools. This is emphasized in the State Educational Standard for Preschool Education, which defines the expectations of society on the development, upbringing and education of preschool children, provides for the formation of the child's competencies, which indicate the ability to actively show personal possessions in various independent and organized adult activities. Among the key competencies for preschool education, our attention is drawn to the game and art and speech. It is the game competence that realizes the child's ability to apply existing and learn new knowledge through the leading type of activity, and artistic and speech - to reproduce artistic and aesthetic impressions from the perception of literary and folklore works by means of different types of artistic and speech activities.

G. Kostyuk, S. Rusova, V. Sukhomlynsky, K. Ushinsky and others made a significant contribution to the development of gaming activities. O. Bezsonova, A. Bogush, N. Bibik, A. Bondarenko, N. Gavrish, A. Matusyk, D. Mendzherytska, T. Pirozhenko, I. Sikorsky, O. Savchenko pointed out the role of play activities in the development and education of preschoolers. M. Shut and others. Fiction as a type of activity that promotes the development of preschoolers was the subject of research A. Bogush, N. Gavrish, V. Kuzmenko, D. Lutsenko, O. Kononko and others. However, despite the significant amount of research in this area, little research has been done on the organization of play activities in the process of acquainting preschoolers with fiction.

With this in mind, the purpose of the article is to investigate the state of use of different types of play activities in acquainting preschool children with works of fiction and to suggest possible ways to use game forms of work in acquainting preschool children with works of art.

It is known that play is the most accessible activity for preschool children, as it corresponds to the mental properties of preschoolers and promotes the development of their interests and abilities. There are many classifications of types of game activities: directing, role-playing, design and construction, games on the themes of literary works, mobile, didactic, folk games and more. It is clear that the creative educator in his activity will be able to use any kind of game when acquainting children with literary works (both with small genre folklore and author's works).

Note that introducing children to folklore (games, sayings, rhymes, appeals, etc.) can offer mobile games, and to learn them you can use mnemonics. When reading and mastering fairy tales (folk or literary) it will be appropriate to conduct story-role or theatrical games. In addition, there are many didactic games that will help children better understand and analyze the content of fairy tales. Among such didactic games are "What rights are violated in the heroes of fairy tales", "Find a couple in a fairy tale (work)", "Find a shadow", "Recognize a fairy tale by drawing", "Collect a fairy tale", "Lotto" and more. During the study of poems (for example, P. Voronko "Sly hedgehog", "Snow fell on the threshold", M. Poznanska "Chamomile", P. Tychyna "And I went to the grove", etc.) and translation of works (for example, L. Ukrainka ("Mother is already winter", "Cherries", "On a green hill", etc.) you can use mnemonics or Lulia's circles, which are also used as a didactic game.

The use of any games while acquainting children with works of art contributes to the development of their memory, attention, consolidation of acquired knowledge and the formation of the ability to use them in practice. The main thing is that the learning process takes place in an interesting way and helps to meet the natural needs of preschoolers - the need for play.

Thus, the development of creativity of preschoolers will depend on the creative approach of adults in teaching and educating children. The types of games we offer during the acquaintance of preschool children with literary works do not limit the wide possibilities for the integration of different types of activities in working with preschool children. We see further research in the study of the use of IT technologies in acquainting preschool children with literary works.

Key words: game, game activity, plot-role game, theatrical game, didactic game, fiction, folklore. 
Актуальність проблеми. Оновлений Базовий компонент дошкільної освіти (Піроженко, 2021) як державний освітній стандарт, що визначає очікування суспільства 3 питань розвиненості, вихованості та освіченості дитини дошкільного віку, передбачає наявність сформованих у дитини компетентностей, які вказують на можливість активно проявляти особистісні надбання в різних самостійних та організованих за підтримки дорослого видах діяльності (Косенчук та ін., 2021: 5). Уваги заслуговує ігрова компетентність як здатність дитини до вільної, емоційно насиченої, спонтанної активності із власної ініціативи, у якій реалізується можливість застосування наявних і освоєння нових знань та особистісного розвитку через прагнення дитини до участі в житті дорослих шляхом реалізації інтересів в ігрових та рольових діях в узагальненій формі (Косенчук та ін., 2021: 210). Ігровий процес як зона найближчого розвитку дитини пронизує всі етапи організації життєдіяльності дитини та інтегрується у різних напрямах розвитку дітей (фізичному, психічному, комунікативному тощо).

Зрозуміло, що, намагаючись виховати здорову, всебічно розвинену особистість, батьки, вихователі та інші зацікавлені особи здійснюють виховний вплив на дитину 3 раннього дитинства. Однією із форм такого впливу дорослі обирають художню літературу. Водночас у цьому напрямі вирішується ще одна компетентність дошкільників - художньо-мовленнєва. Згідно з Базовим компонентом дошкільної освіти художньо-мовленнєва компетентність це здатність відтворювати художньо-естетичні враження від сприйняття літературних і фольклорних творів засобами різних видів художньо-мовленнєвої діяльності, що засвідчує ціннісне ставлення дитини до художнього слова як культурного явища, друкованої чи електронної книжки, достатній для художньої комунікації рівень літературної обізнаності (Косенчук та ін., 2021: 215).

3 огляду на вищезазначене, своєчасним та актуальним є розгляд питання щодо можливості використання ігрової діяльності під час ознайомлення дітей 3 різними видами художньої літератури.

Аналіз останніх досліджень i публікацій дав змогу підкреслити інтерес науковців до питання ігрової діяльності дітей. У статті
Лариси Азарової та Наталії Франчук гра представлена як вид креативної діяльності людини, у процесі якої в уявній формі відтворюються способи дій із предметами, стосунки між людьми, відбуваються важливі зміни у психіці дошкільника й розвиваються процеси, що готують його перехід до нового, вищого щаблю розвитку (Азарова, Франчук). Вагомість ігрової діяльності в розвитку і вихованні дошкільників розкривали О. Безсонова, А. Бондаренко, Н. Гавриш, А. Матусик, Д. Менджерицька, Т. Піроженко, М. Шуть та інші. На роль гри в освітній діяльності вказувала А. Богуш, Н. Бібік, Н. Луцан, І. Сікорський, О. Савченко та інші. Однак варто звернути увагу, що сучасні дослідники спираються на напрацювання вітчизняних і зарубіжних учених минулих років: Г. Костюка, С. Русової, В. Сухомлинського, К. Ушинського та інших.

Не залишається поза увагою науковців і питання художньої літератури як виду діяльності у розвитку дошкільників. А. Богуш, Н. Гавриш, В. Кузьменко, Д. Луценко, О. Кононко та низка інших учених вказують на роль дитини та розвиток у неї уявлень і почуттів у процесі художньо-естетичного сприймання літературних та інших художніх творів. М. Байбароша розглядала питання художніх літературних творів як засобу виховання дітей дошкільного віку (Байбароша). Вирішення проблем щодо змісту та методики ознайомлення дітей із жанрами художніх літературних творів, їх значення у житті дошкільників вивчала Г. Ватаманюк (Ватаманюк, 2007).

Незважаючи на значну кількість досліджень у цьому напрямі, мало дослідженим $є$ питання організації ігрової діяльності у процесі ознайомлення дошкільників із художньою літературою.

Мета дослідження. Дослідити стан використання різних видів ігрової діяльності під час ознайомлення дітей дошкільного віку із творами художньої літератури та запропонувати можливі способи використання ігрових форм роботи під час ознайомлення дітей дошкільного віку із художніми творами.

Виклад основного матеріалу дослідження. Беззаперечно, художня література та ігрова діяльність є гармонійним поєднанням в освітньому процесі дошкільників, оскільки діти люблять слухати казки, читати книжки, запам'ятовувати вірші не менше, ніж гратися, малювати тощо. 
Відомо, що діяльність дітей дошкільного віку проходить у грі, у процесі якої вони фантазують, тому у дошкільників виникає потреба у художніх творах для гри, інсценізації тощо. Для того, щоб підібрати та описати різні види ігор у процесі ознайомлення із художніми творами, з'ясуємо, що таке ігрова діяльність, які існують види ігор та жанри художньої літератури.

Ігрова діяльність $є$ найдоступнішим видом діяльності для дітей дошкільного віку, оскільки відповідає психічним властивостям дошкільників та сприяє розвитку їхніх інтересів та здібностей. Дитяча гра трактується як діяльність, спрямована на орієнтування у предметній і соціальній дійсності, в якій дитина відображає враження від їх пізнання (Поніманська, 2013: 315).

У наукових джерелах можна знайти численну кількість різних видів ігор, запропонованих В. Штерном, Ж. Піаже, С. Русовою, К. Гарвей, С. Новосьоловою та іншими. Існує й сучасна класифікація ігор, згідно з якою виділяють творчі ігри (режисерські, сюжетно-рольові, конструкторсько-будівельні, ігри на теми літературних творів), ігри за правилами (рухливі ігри, дидактичні ігри), народні ігри (Московченко). Передбачаємо, що будь-який із вказаних видів ігрової діяльності можна використати під час ознайомлення дітей із літературними творами.

Як зазначає Г. Ватаманюк, «дошкільнята в основному не читачі, а слухачі художніх творів, тому вихователю для читання і розповідання треба використовувати твори різних жанрів. Випускники дошкільного навчального закладу мають знати й використовувати у спілкуванні з довкіллям приказки, прислів'я, каламбури, колядки, щедрівки, скоромовки, загадки, лічилки, народні казки» (Ватаманюк, 2007: 240). Окрім малого жанрового фольклору, у роботі з дошкільнятами збільшується увага до ознайомлення із творами класиків української літератури (Т. Шевченко, Л. Українка, І. Франко, Л. Глібов, М. Коцюбинський, Є. Гребінка, М. Вовчок, О. Пчілка, Я. Щоголів, С. Руданський) та сучасних українських письменників (П. Тичина, М. Рильський, В. Сосюра, О. Вишня, А. Малишко, М. Стельмах, П. Воронько, Л. Костенко, О. Гончар, Т. Коломієць та інші). Враховуючи це, спробуємо запропонувати різні ігрові дії у процесі ознайомлення дошкільників як із малими жанрами фольклору, так і з авторськими творами.
Відомо, що дітям дошкільного віку подобається гратися у сюжетно-рольові ігри, під час яких дитина будує сюжет і керує обраною роллю (Курінна, Любчак, 2017). Аналізуючи освітню програму «Дитина» (Огнев'юк, Бєлєнька, 2020), переконуємося у можливості та необхідності використання рольових ігор за змістом художньої літератури. Наприклад, для дітей старшої групи пропонуються сюжетно-рольові ігри «Книгарня», «Бібліотека», «Книжкова виставка», «Крамниця», «Видавництво», під час яких діти мають можливість ознайомитися з історією створення книжки, професіями людей, причетних до створення книги, різними видами книги тощо.

Використання сюжетно-рольової гри можливе і під час ознайомлення дітей 3 українськими та авторськими казками. Наприклад, до казки «Ріпка» можна запропонувати пограти у настільну сюжетно-рольову гру, під час якої відбувається залучення дітей до ознайомлення із казкою, взаємодія у процесі вільної діяльності, а також діти програють комунікативні дії, які не спрямовані на іншу дитину, таким чином їм легше наполягати, нав'язувати, підпорядковувати, вказувати тощо (Піроженко, 2020). Для закріплення української народної казки «Рукавичка» можна запропонувати дітям пограти у рухливу сюжетно-рольову гру, що дає можливість дитині, діючи відповідно до ролі, повніше використати свої можливості і задовольнити багато потреб (фізичних, розумових, естетичних тощо).

Цікавим для дітей дошкільного віку є проведення театралізованих ігор, що передбачає розігрування в особах літературного твору, відтворення за допомогою виражальних засобів (інтонації, міміки, жестів, пози, ходи) конкретних образів (Поніманська, 2013: 378). Ці ігри можна пропонувати для закріплення як українських народних казок («Рукавичка», «КозаДереза», «Ріпка», «Солом'яний бичок» тощо), так і інших літературних творів («Приємні клопоти» М. Пономаренко, «Хлопчик та ведмідь» О. Пчілки тощо). Варто зазначити, що використання театралізованих ігор, на відміну від проведення сюжетно-рольових ігор, вимагає більшої підготовки та дотримання послідовність подій, ролей, мови героїв, що визначаються текстом літературного твору. 
Зазначимо, що головним під час проведення будь-яких ігор є задоволення потреб дитини, а саме: у русі, у спілкуванні, в образному поетичному слові. Діти дошкільного віку завжди прагнуть до чогось незвичного, веселого, а позитивні емоції захищають дітей від розумових перевантажень (Піроженко, 2020: 18). 3 цією метою доречним є використання ігорзабав, які приносять дитині радісні переживання, захоплюють іiі, не вимагаючи при цьому особливих фізичних та розумових зусиль. Поєднання рухів із словом сприяють усвідомленню змісту гри, що, у свою чергу, полегшує виконання ігрових дій. Ігри-забави можна запропонувати під час ознайомлення із фольклорними творами, такими як забавлянки («Два півники», «Кую-кую чобіток» тощо), примовки («Купалися ластів'ята», «Водичко, водичко, умий моє личко...» тощо), та 3 авторськими віршами («Хлюп, хлюп водиченько» Г. Бойка, «Ладки, ладки, ладусі» Н. Забіли, «Киця прокидається» А. М'ястківського) тощо.

Для нас особливий інтерес становлять дидактичні ігри та можливість їх використання під час ознайомлення з літературними творами. Зазначимо, що дидактичні ігри (ігрові заняття і прийоми) підвищують ефективність сприймання дітьми навчального матеріалу, урізноманітнюють їхню навчальну діяльність, вносять у неї елемент цікавості (Поніманська, 2013). Використовувати дидактичні ігри можна, навіть потрібно, у навчанні та вихованні дітей усіх вікових груп, це сприятиме актуалізації їхнього досвіду, повторенню й закріпленню набутих знань тощо. Зупинимося на цьому більш детально.

Розвиваючи уміння дітей встановлювати причинно-наслідкові зв'язки, робити припущення та висновки, закріплювати прочитаний раніше матеріал, можна запропонувати дидактичну гру «Які права порушено у героїв казок». При цьому можна пригадати такі казки, як «Лисиця і вовк», «Івасик-Телесик», «Кривенька качечка», «Три ведмеді», «Рукавичка», «Колобок», «Лисиця та Журавель», «Червона шапочка», «Кіт у чоботях» (Шарль Перо) тощо. За змістом таких прочитаних творів, як «Колобок», «Півник та котик», «Лисичка-сестричка та Вовк-панібрат», «Хліб чи халва?» (І. Січовик), можна запропонувати дидактичну гру «Послуги і товари у казках», під час якої діти закріплюють знання про те, що таке послуги і товари, виховують повагу до будь-якої праці.

Варто зазначити, що дидактичні ігри підбираються відповідно до того, яке завдання потрібно вирішити. Наприклад, для уміння дітей переказувати зміст прочитаного твору чи казки можна пропонувати дидактичні ігри, зроблені на основі кругів Лулія (наприклад, В.О. Сухомлинського «Чого синичка плаче?», «Старий пень», «Чому дідусь такий добрий сьогодні?», казки «Рукавичка», «Колобок», «Солом'яний бичок» тощо).

Мнемотаблиці для розучування віршів (П. Воронько «Їжачок-хитрячок», «Падав сніг на поріг», М. Познанська «Ромашка», П. Тичина «А я у гай ходила» тощо), переказу творів (Л. Українки «Мамо, іде вже зима», «Вишеньки», «На зеленому горбочку» тощо), мирилок, потішок та забавлянок допоможуть дошкільникам запам'ятовувати та відтворювати художні творі.

Або ж можна запропонувати мнемотаблиці для переказу казки («Лисичка-сестричка та Вовк-панібрат», «Котик і півник» тощо) чи твору (наприклад, В. О. Сухомлинського «Бабусин борщ», «Дивна бурулька» тощо).

Для розвитку умінь дітей співвідносити предмети і героїв твору можна запропонувати дидактичні ігри «Лото», «Знайди в казці (творі) пару», «Відшукай тінь» або дидактичну гру «Впізнай казку за малюнком» чи гру «Збери казку». Використання таких ігор сприятиме розвитку у дітей пам'яті, уваги, закріпленню набутих знань i формуванню уміння використовувати їх на практиці. Головне, що процес навчання відбувається у цікавій формі та сприяє задоволенню однієї із природних потреб дошкільників - потреби у грі.

Висновки і перспективи подальших досліджень. Отже, розвиток креативності дошкільників буде залежати від творчого підходу дорослих у навчанні та вихованні дітей. Пропоновані нами види ігор під час ознайомлення дітей дошкільного віку 3 літературними творами не обмежують широкі можливості для інтеграції різних видів діяльності у роботі з дітьми дошкільного віку. Перспективи подальших досліджень вбачаємо у дослідженні використання IT-технологій під час ознайомлення дітей дошкільного віку 3 літературними творами. 


\section{ЛІТЕРАТУРА:}

1. Азарова Л., Франчук Н. Організація ігрової діяльності дошкільників як соціально-педагогічна проблема. URL: https://www.pulib.sk/web/kniznica/elpub/dokument/Bernatova8/subor/Azarova_Franchuk.pdf

2. Базовий компонент дошкільної освіти (Державний стандарт дошкільної освіти): Нова редакція. Під науковим керівництвом: Т.О. Піроженко. К. 2021. 37 с.

3. Байбароша M.O. Художні літературні твори як засіб виховання дітей дошкільного віку. URL: https://vseosvita.ua/library/hudozni-literaturni-tvori-ak-zasib-vihovanna-ditej-doskilnogo-viku-290168.html

4. Ватаманюк Галина Художня література як засіб формування духовного світу дитини. Збірник наукових праць Кам'янець-Подільського держ. університету. Серія педагогічна. Кам'янець-Подільський, 2007. Вип. XIII. С. 237-240.

5. Державний стандарт дошкільної освіти: особливості впровадження. Упорядники: О.Г. Косенчук, І.М. Новик, О.А. Венгловська, Л.В. Куземко. Харків : Вид-во «Ранок», 2021. 240 с.

6. Дитина: Освітня програма для дітей від двох до семи років / наук. кер. проекту В.О. Огнев'юк; наук. ред. В.Г. Бєлєнька. Київ : Київський університет імені Б. Грінченка, 2020. 440 с.

7. Ігрова діяльність дошкільника: молодший дошкільний вік / Піроженко Т.О. та ін. Київ : Генеза. 2020. 88 с.

8. Курінна С.М., Любчак В.О. Роль гри у соціальному становленні особистості дитини дошкільного віку. «Молодий вчений». № 10.1 (50.1). жовтень, 2017 p.

9. Московченко Вікторія Сергіївна Організація ігрової діяльності дітей раннього віку. URL: https://vseosvita.ua/ library/organizacii-igrovoi-dialnosti-ditej-rannogo-viku-203337.html

10. Організація ігрової діяльності дітей дошкільного віку. 2-ге вид. / авт.-упор. А. П. Бурова. Тернопіль : Мандрівець, 2013. 296 с.

11. Поніманська Т.І. Дошкільна педагогіка. Навчальний посібник. 2-е видання, доповнено. К. Академвидав, 2013. $464 \mathrm{c}$.

\section{REFERENCES:}

1. Azarova L., Franchuk N. Orghanizacija ighrovoji dijaljnosti doshkiljnykiv jak socialjno-pedaghoghichna problema [Organization of play activities of preschoolers as a socio-pedagogical problem]. https:/www.pulib.sk/web/kniznica/ elpub/dokument/Bernatova8/subor/Azarova_Franchuk.pdf (in Ukrainian)

2. Pirozhenko T.O. (2021) Bazovyj komponent doshkiljnoji osvity (Derzhavnyj standart doshkiljnoji osvity) [Basic component of preschool education (State standard of preschool education): New edition. Under the scientific guidance:]. K. 37 p. (in Ukrainian)

3. Baibarosha M.O. Khudozhni literaturni tvory jak zasib vykhovannja ditej doshkiljnogho viku [Fiction as a means of educating preschool children]/ https://vseosvita.ua/library/hudozni-literaturni-tvori-ak-zasib-vihovanna-ditej-doskilnogoviku-290168.html. (in Ukrainian)

4. Vatamanyuk Halyna (2007) Khudozhnja literatura jak zasib formuvannja dukhovnogho svitu dytyny [Fiction as a means of forming the spiritual world of the child. Collection of scientific works of Kamyanets-Podilsky state. university. The series is pedagogical]. Kamyanets-Podilsky, Issue. XIII. Pp. 237-240. (in Ukrainian)

5. Kosenchuk O.G., Novik I.M., Venglovska O.A., Kuzemko L.V. (2021) Derzhavnyj standart doshkiljnoji osvity: osoblyvosti vprovadzhennja [State standard of preschool education: features of implementation.]. Kharkiv : Ranok Publishing House, 240 p. (in Ukrainian)

6. Ognevyuk V.O., Belenka V.G. (2020) Dytyna: Osvitnja proghrama dlja ditej vid dvokh do semy rokiv [Child: Educational program for children from two to seven years / science. ker. project; Science. ed. K. : B. Hrinchenko University of Kyiv]. 440 p. (in Ukrainian)

7. Pirozhenko T.O. (2020) Ighrova dijaljnistj doshkiljnyka : molodshyj doshkiljnyj vik [Play activity of a preschooler: junior preschool]. Kyiv : Genesis. 88 p. (in Ukrainian).

8. Kurinna S.M., Lyubchak V.O. (2017) Rolj ghry u socialjnomu stanovlenni osobystosti dytyny doshkiljnogho viku [The role of play in the social development of the personality of a preschool child. "Young scientist"]. № 10.1 (50.1). October. (in Ukrainian)

9. Moskovchenko V.S. Orghanizacija ighrovoji dijaljnosti ditej rannjogho viku. [Organization of play activities of young children]. Electronic resource: https://vseosvita.ua/library/organizacii-igrovoi-dialnosti-ditej-rannogoviku-203337.html (in Ukrainian)

10. Orghanizacija ighrovoji dijaljnosti ditej doshkiljnogho viku [Organization of play activities for preschool children]. 2nd type. / avt.-upor. A.P. Burov (2013). Ternopil: Mandrivets, 296 p. (in Ukrainian)

11. Ponimanskaya T.I. (2013) Doshkiljna pedaghoghika [Preschool pedagogy. Tutorial. 2nd edition, supplemented]. K. Akademvidav, 464 p. (in Ukrainian) 